University of Northern lowa

UNI ScholarWorks

Faculty Publications

Faculty Work

1998

\title{
Art, Design and Gestalt Theory
}

Roy R. Behrens

University of Northern lowa

Let us know how access to this document benefits you

Copyright (C)1998 The MIT Press

Follow this and additional works at: https://scholarworks.uni.edu/art_facpub

Part of the Art and Design Commons

\section{Recommended Citation}

Behrens, Roy R., "Art, Design and Gestalt Theory" (1998). Faculty Publications. 2.

https://scholarworks.uni.edu/art_facpub/2

This Article is brought to you for free and open access by the Faculty Work at UNI ScholarWorks. It has been accepted for inclusion in Faculty Publications by an authorized administrator of UNI ScholarWorks. For more information, please contact scholarworks@uni.edu. 


\title{
Art, Design and Gestalt Theory
}

\author{
Roy R. Behrens
}

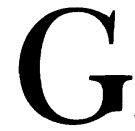

estalt psychology began in Germany in 1910. While traveling by train on vacation, a 30 -year-old Czech-born psychologist named Max Wertheimer was seized by an idea when he saw flashing lights at a railroad crossing that resembled lights encircling a theater marquee. He got off the train in Frankfurt am Main, where he bought a motion picture toy called a "zoetrope" (Fig. 1). When a strip of pictures is placed inside and viewed through the slits in a zoetrope, a succession of stationary pictures appear to be a single, moving picture. In his hotel room, Wertheimer made his own picture strips, consisting not of identifiable objects, but of simple abstract lines, ranging from vertical to horizontal. By varying these elements, he was able to investigate the conditions that contribute to the illusion of motion pictures, an effect that is technically known as "apparent movement" [1].

Years earlier, Wertheimer had studied in Prague with an Austrian philosopher named Christian von Ehrenfels, who had published a paper in 1890 entitled "On Gestalt Qualities" in which he pointed out that a melody is still recognizable when played in different keys, even though none of the notes are the same, and that abstract form attributes such as "squareness" or "angularity" can be conveyed by a wide range

Fig. 1. Engraving of a zoetrope, a motion picture toy invented in England before 1850 by W.G. Horner. This is the toy that Wertheimer bought when he left the train at Frankfurt am Main in 1910.

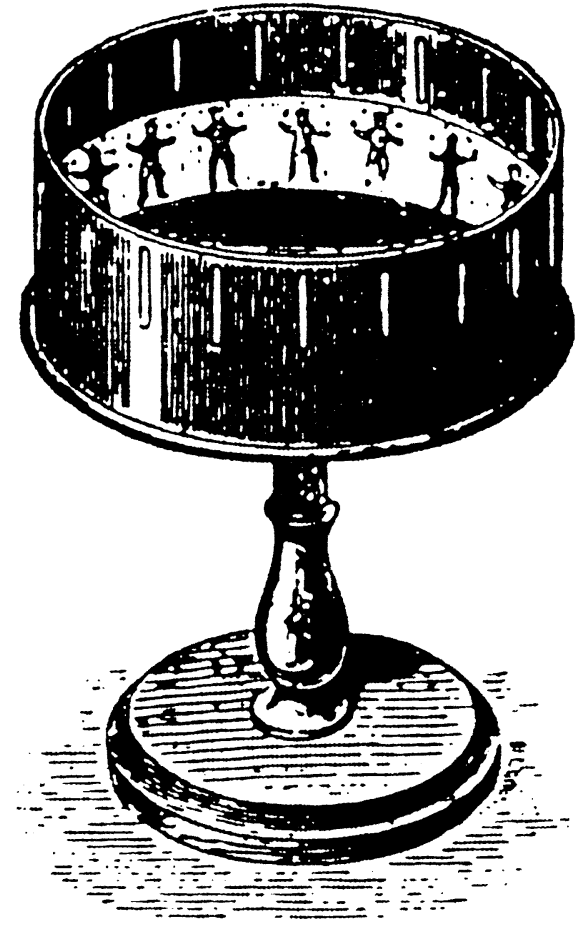

of specific elements. Clearly, argued Ehrenfels, if a melody and the notes that comprise it are so independent, then a whole is not simply the sum of its parts, but a synergistic "whole effect," or gestalt [2]. Likewise, Wertheimer concluded, the effect of apparent movement is generated not so much by its individual elements as by their dynamic interrelation.

Wertheimer remained in Frankfurt for more than 5 years. He continued his research of apparent movement at the Psychological Institute, where he used a sophisticated projector called a "tachistoscope" that enabled him to flash shapes on the screen successively for precise increments of time. He recruited as subjects two younger psychologists, Kurt Koffka and Wolfgang Köhler. After gathering data for more than a year, he shared the results with his colleagues, then published his findings in 1912 in a paper titled "Experimental Studies of the Perception of Movement" [3]. This was the first important event in the history of gestalt psychology, a movement that grew from the subsequent work of its prodigious triumvirate: Wertheimer, Koffka and Köhler.

The three founding gestalt psychologists were separated by World War I, then reunited in 1920, when Köhler became Director of the Psychological Institute at the University of Berlin, where Wertheimer was already a faculty member. While maintaining contact with Koffka, who continued to teach near Frankfurt, Wertheimer and Köhler established a graduate program, located in the abandoned Imperial Palace, and began a research journal called Psychologische Forschung (Psychological Investigation). For the most part, the students did not learn by attending lectures but by actually conducting research using fellow students as subjects and by preparing articles for publication. The success of the method is evidenced by the number of teachers and students at the Institute whose names are now familiar in psychology, including Rudolf Arnheim, Kurt Lewin, Wolfgang Metzger, Hans Wallach, Bluma Zeigarnik, Tamara Dembo, Karl Duncker, Maria Ovsiankina, Herta Kopfermann and Kurt Gottschaldt [4].

Koffka left Europe for the United States in 1924; Wertheimer in 1933. By the early 1930s, the Psychological Institute had begun to erode. When the National Socialists came to power in 1933, among their immediate menacing acts was the dismissal of Jewish university professors, from

Roy R. Behrens, (artist, writer, teacher), 2022 X Avenue, Dysart, IA 52224-9767, U.S.A. E-mail: <ballast@netins.ne〉. 


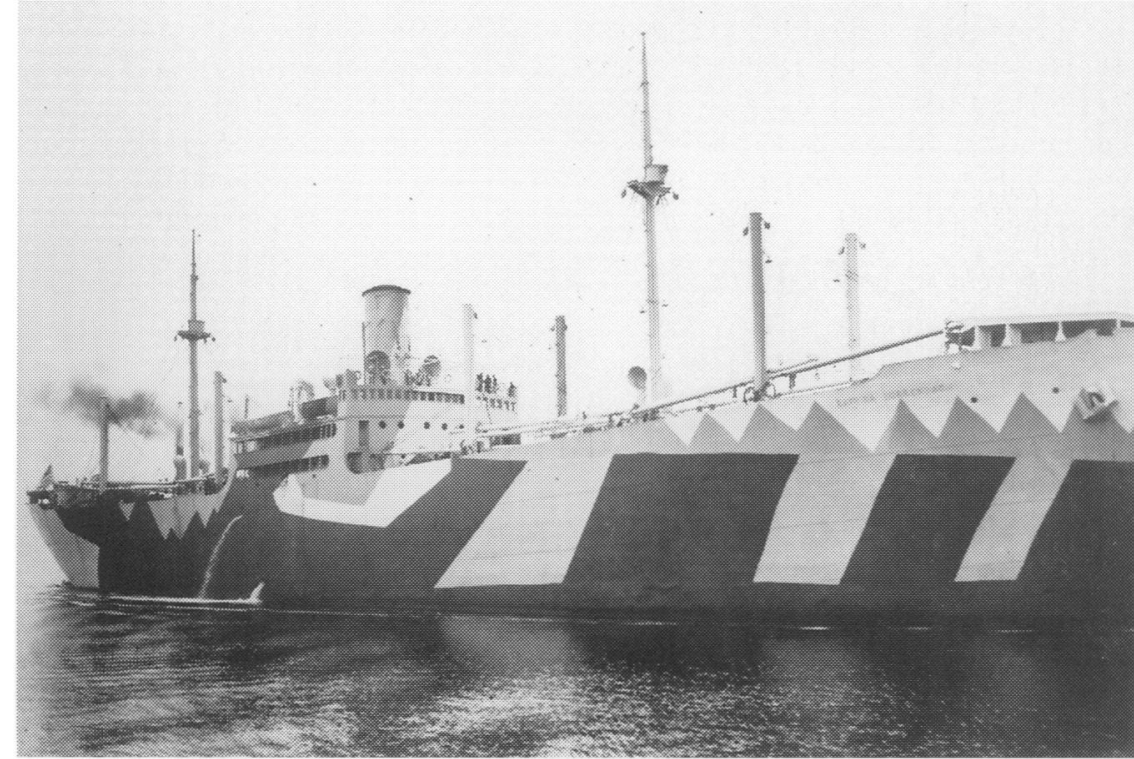

Fig. 2. World War I American ship camouflage, intended to confuse the aim of German Uboat torpedo gunners (circa 1918). That perceptual grouping tendencies are inborn and universal is suggested by the cross-cultural effectiveness of camouflage, which reliably works by subverting the "laws" that the gestalt psychologists postulated. In high-similarity, or blending, camouflage, objects and their surroundings are so similar as to be nearly indistinguishable. In high-difference, or dazzle, camouflage, as in this example, the continuity of a shape is interrupted by a surface design of unrelated, contrasting elements. (Photo courtesy of National Archives and Record Service)

Nobel Prize scientists to graduate assistants. Rumored as being in sympathy with "the Jew Wertheimer," Köhler publicly condemned anti-Semitism and protested the dismissals in a Berlin newspaper article, the last such article allowed under the Nazis. To his surprise, he was not arrested, but the intimidation mounted, and in 1935, he too emigrated to the United States [5].

None of the gestalt psychologists were artists, much less designers, but early on there were signs of a mutual interest between the two disciplines. In 1927, for example, gestalt psychologist Rudolf Arnheim visited the Dessau Bauhaus, then published an article in Die Weltbühne praising the honesty and clarity of its building design [6]. Soon after, gestaltist Kurt Lewin commissioned Peter Behrens (teacher of Bauhaus founder Walter Gropius) to design his home in Berlin, but, after a disagreement, Bauhaus furniture designer Marcel Breuer was asked to complete the interior [7]. In 1929, Köhler declined a Bauhaus invitation to lecture because of a scheduling conflict, so his student Karl Duncker spoke instead. In the audience was the painter Paul Klee, who had known about Wertheimer's research as early as 1925 [8]. But other Bauhaus artists were also interested, including Wassily Kandinsky and Josef Albers, both of whom attended a series of lectures about gestalt theory by Count Karlfried von Dürckheim, a visiting psychologist from the University of Leipzig, in the winter of 1930-1931 [9].

Albers's curiosity about gestalt theory may be significant because he is now commonly credited with a resurgence of interest in "simultaneous contrast," which von Dürckheim discussed in his lectures. Recognized and used by artists for centuries, the effect was described scientifically in 1839 by a French chemist, Michel-Eugene Chevreul, who essentially found that a color may appear to change, often dramatically, when moved from one background to another. A swatch of red, for example, may exhibit one intensity on a green background, another on orange. As a result of this phenomenon, there is no easy answer to the question "What is the true appearance of a color?" Simultaneous contrast anticipated holism, in the sense that gestaltists are likely to say that all such appearances of a color are legitimate, because we always experience perceptual wholes, not isolated parts. We never see figures (or swatches) alone, only dynamic "figure-ground" relationships [10].

Of equal interest is Albers's and graphic designer László Moholy-Nagy's emphasis on unusual uses of common materials in the Bauhaus foundations course, in which students were pre- sented with discarded materials (wire mesh, cardboard, newspapers, matchboxes, phonograph needles and razor blades) and instructed to basteln-to improvise or "rig up" something. It is said that this method was influenced by Friedrich Froebel's pedagogy of "education through play" (in part because Johannes Itten, who started the foundations course, was a Froebel-trained elementary school teacher), especially the celebrated Froebel "gifts" (cited by Frank Lloyd Wright as pivotal in his early education), which were sets of wooden blocks, presented in sequence to children between the ages of 2 months and 6 years, that could be rearranged in a variety of configurations [11].

This is also surprisingly similar to gestalt psychologist Duncker's "functional fixedness" experiments, published in 1935 , in which subjects were asked to improvise solutions to various problems using seemingly inappropriate materials. In one, for example, the subject was shown a table with a variety of common items on it, including a cord, nail and weight scattered among them, and asked to construct a pendulum. Most solved the problem by using the weight as a hammer to pound the nail into the wall, tying the cord to the weight and suspending the improvised pendulum from the nail. But that solution occurred less readily to other subjects if, during instructions, the weight was described as a "pendulum weight" and already tied to the cord. In such instances,

Fig. 3. Ryan McAdam, trademark for a hypothetical restaurant called Dada Café (1996). The gestalt psychologists described the effects of similarity grouping, the innate tendency to constellate or to see as belonging together elements that look alike. Anticipating that tendency, the designer of this logo has set up deliberate visual rhymes by the recurrent use of circular shapes, s-shaped scallops and several thicknesses of line.

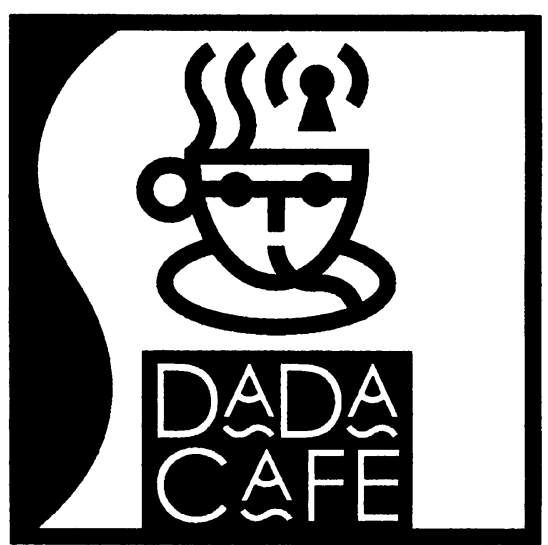




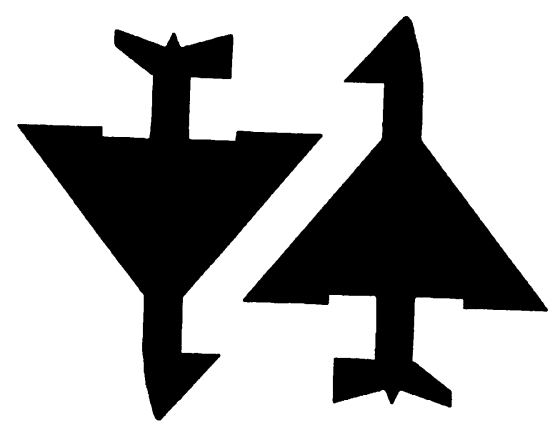

Fig. 4. Thomas J. Lechtenberg, trademark for a hypothetical airline company (1996). In this example of reversible figure-ground, the white background area between the two airplanes can be perceived as a " $Z$ " by switching attention from figure to ground. Comparable phenomena can be found in the traditional Chinese yin-yang symbol, and in the compositional equivalence of light and dark (or positive and negative) called notan in Japanese art.

Duncker concluded, the weight and the cord were assumed to be linked (as a gestalt), verbally and visually, making it difficult to perceive the weight separately as a hammer [12].

What may be gestalt psychology's most enduring influence on art and design came from a paper by Max Wertheimer titled "Theory of Form," published in 1923 [13]. Nicknamed "the dot essay" because it was illustrated with abstract patterns of dots and lines, Wertheimer concluded in it that certain gestalts are enhanced by our innate tendencies to constellate, or to see as "belonging together" elements that look alike (called "similarity grouping"), are close together ("proximity grouping") or have structural economy ("good continuation"). That such tendencies are inborn, not learned, is suggested by the cross-cultural effectiveness of sleight-of-hand magic and camouflage, both of which work by subverting the "laws" described in Wertheimer's paper (Fig. 2). But the interplay of such grouping tendencies is far from simple, because: (1) as the effect of simultaneous contrast discussed earlier demonstrates, the appearance of parts is determined by wholes; (2) judgments about similarity or proximity are always comparative; and (3) in compositions as intricate as paintings, posters and page layouts, parts may be purposely made to connect by one grouping tendency (similarity of color, for example) but to disconnect by others (distance, for example, or differences of shape, size or direction) (Fig. 3) [14].

It is likely that few artists were directly aware of Wertheimer's dot essay, one exception being Paul Klee, who (as Marianne Teuber has shown) used some of its diagrams in his paintings in the 1930s [15]. Rather, they learned about his "laws of visual organization" from other writings, long after the essay was first published, and particularly from two books that had an enormous and lasting effect on art and design education: Language of Vision (1944) by György
Kepes, a Hungarian-born graphic designer who taught with Moholy-Nagy at the New Bauhaus in Chicago; and Art and Visual Perception: A Psychology of the Creative Eye (1954) by Rudolf Arnheim, a Berlin gestaltist who emigrated to the United States, became professor of the Psychology of Art at Harvard University and published 13 books on gestalt theory and art [16].

Surely, one of the reasons artists embraced gestalt theory is that it provided, in their minds, scientific validation of age-old principles of composition and page layout. A French byname for gestalt theory is la psychologie de la forme. Inadvertently, due to its emphasis on flat abstract patterns, structural economy and implicitness, gestalt theory became associated with the modernist tendency toward "aestheticism," the belief thatlike music and architecture-all art is essentially abstract design and, as Ellen Lupton and J. Abbott Miller characterize it in Design Writing Research (1996), that "design is, at bottom, an abstract, formal activity" in which the "text [or subject matter] is secondary, added only after the mastery of form" [17].

Aestheticism had been anticipated in 1851 by John Ruskin in a passage in Stones of Venice, the book that spawned the arts and crafts movement, in which he stated that "the arrangement of colors and lines is an art analogous to the composition of music, and entirely independent of the representation of facts"

Fig. 5. Lisa James, (left) collage portrait of Sigmund Freud (1996). (right) Underlying this composition of typographic and pictorial elements is an implied grid system, an arrangement of intersecting lines that resembles Oriental lattice patterns and plaid fabrics, like those illustrated in Arthur Dow's Composition. As anticipated by gestalt theory, edges that align in space appear to belong together. Tartan compositional grids are widely used in graphic design, especially in page layouts.

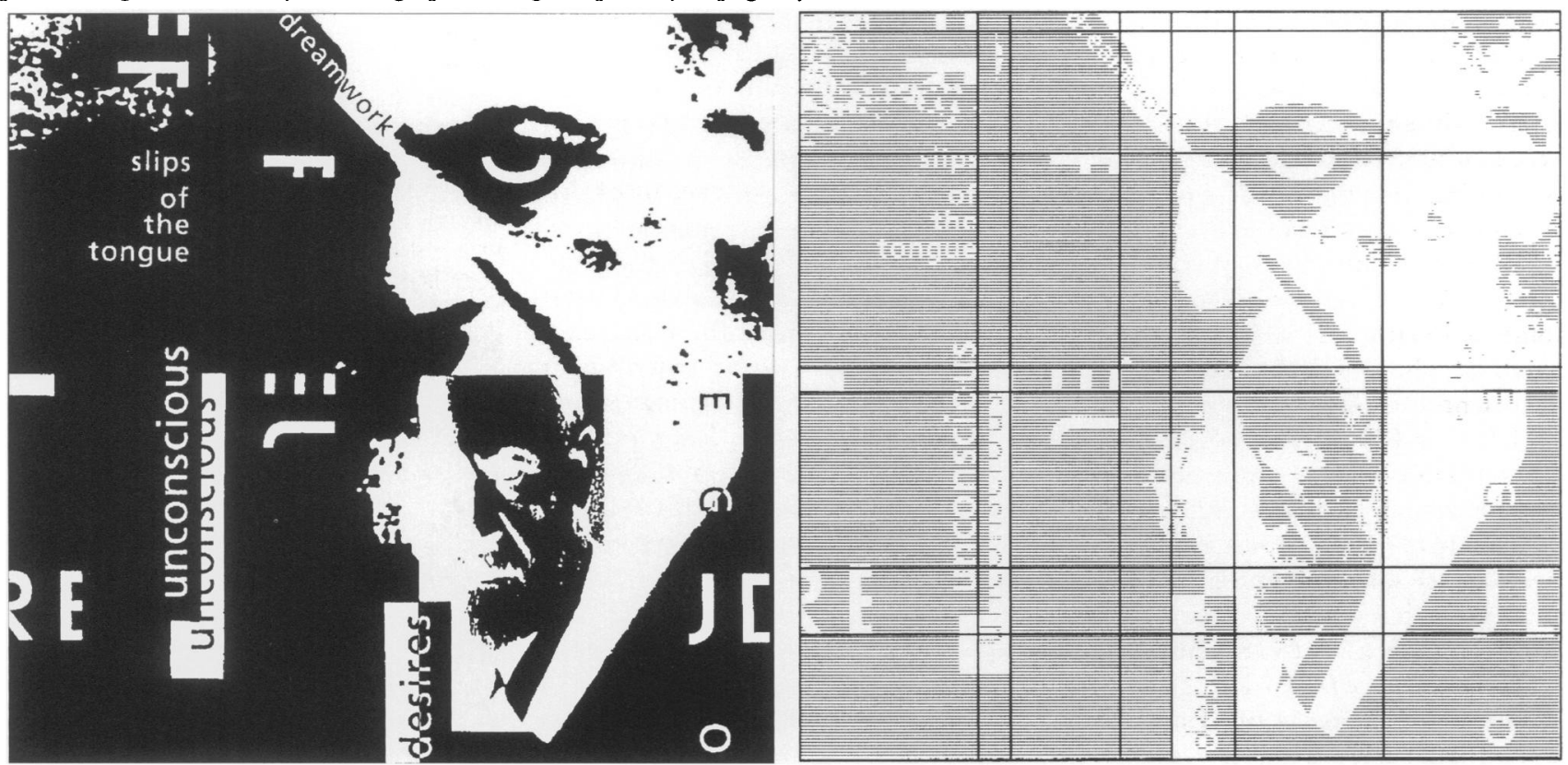


[18]. More than 2 decades later, this view was reaffirmed by James A.M. Whistler, a leading figure in the aesthetic movement, for which the unfortunate slogan became "art for art's sake." "As music is the poetry of sound," Whistler wrote in 1878 (in The Gentle Art of Making Enemies), "so is painting the poetry of sight, and the subject-matter has nothing to do with harmony of sound or of color" [19]. To underscore the analogy between art and music, and to promote the idea of art as design, he included in the titles to his paintings musical terms such as "arrangements," "nocturnes" and "harmonies."

Like many of his contemporaries, Whistler was fascinated by Japanese art, especially Ukiyo-e woodblock prints, which were introduced to Europe and America after Japanese ports were opened to foreign trade in 1854. At the close of the nineteenth century, there was a frenzy of interest in things Japanese (a trend called "Japonisme"), which was fueled by a handful of popular books by British, American and Japanese authors, notably Ernest Fenollosa's The Masters of the Ukiyo-e (1896), Arthur Dow's Composition (1899), Denman W. Ross's A Theory of Pure Design (1906) and Kakuzo Okakura's The Book of Tea (1906) [20]. Published in more than 20 editions between 1899 and the early 1940s, Dow's book in particular had a far-reaching effect on the formal training of artists, designers and architects in the United States.

There is a persuasive resemblance between gestalt principles and the Japanese-inspired aesthetics that Dow and others propagated. For example, the gestalt emphasis on the dynamic interplay of parts and wholes had been anticipated as early as the third century в.c. in China by a passage in the Tao Te Ching that states that although a wheel is made of 30 spokes, it is the space between the spokes that determines the overall form of the wheel. The phenomenon of reversible figure-ground (Fig. 4) has precedents in the yin-yang symbol and, in Japanese art, in the compositional equivalence of light and dark, called notan. The gestaltists' ideas of structural economy and closure (the tendency to perceive incomplete forms as complete) are echoed in the Japanese emphasis on elimination of the insignificant and in the ideas of implicitness and the active complicity of the viewer, because genuine beauty, as Okakura explained, "could be discovered only by one who mentally completed the incomplete"
[21]. Even the research of embedded figures by gestaltist Kurt Gottschaldt has an astonishing parallel in Dow's use of tartan compositional grids (Fig. 5), which were adapted from Oriental lattice patterns and apparently applied by Frank Lloyd Wright and Piet Mondrian in architecture and painting, respectively [22].

While Japanese aesthetics contributed to the trend toward geometric abstraction in turn-of-the-century art and design, there is no evidence that the gestalt psychologists were directly or knowingly influenced by either Japanese art or aestheticism. "Our place at the Imperial Palace," recalled Rudolf Arnheim in a letter in 1995, "was as monastically inbred as most scientific breeding places, and although people like Köhler and Wertheimer were interested in art and music, less in literature, [the influences of Japonisme and the Aesthetic Movement] had no resonance there. For me, they all came later. Okakura's The Book of $T e a$ is still one of my cherished possessions, and so is a booklet by Fenollosa on Chinese ideographs. . . A book by Dow on composition is unknown to me even now" [23].

Wertheimer and Koffka died in the early 1940s; Köhler in 1967. Today, gestalt theory's influence in the field of psychology is unobtrusive in the sense that its findings have all been absorbed by more recent viewpoints and because most of the prominent gestalt psychologists have either retired or died. The notable exception is Arnheim, now in his early 90 s, who continues to write provocative essays on psychology and art and whose latest book on art, a collection of essays titled The Split and the Structure, was published in 1996 [24].

In recent years, Arnheim has been outspoken in his criticism of some aspects of postmodern culture, as implied by the title of one of his books, To the Rescue of Art. There are impairments in current design, he believes, that cultivate "an unbridled extravagance, a vulgarity of taste, and a triviality of thought" [25]. In return, some postmodern critics, particularly Lupton and Miller, have attacked gestalt theory as interpreted by Arnheim, Kepes and Donis A. Dondis (author of A Primer of Visual Literacy), contending that it "isolates visual perception from linguistic interpretation [and thereby] encourages indifference to cultural meaning." To study abstract composition is not in itself objectionable, they argue, but "design's linguistic and social aspects are trivialized or ignored when abstraction is made the primary focus of design thinking" [26].

Curiously, Lupton and Miller use comparable methods to disavow gestalt theory: They abstract, simplify and reinterpret it, isolating it from much of its historical, linguistic and social background and, thereby, ironically, largely ignore its "cultural interpretation." A final irony is that their own elegant books make exaggerated use of haute couture typography and page layouts, with purposely dissonant grouping effects, embedded tartan grids and structural economy-devices that Wertheimer sought to explain in 1910 when he founded gestalt psychology.

\section{References and Notes}

1. For detailed information on Wertheimer's apparent movement experiments and the formulation of gestalt theory, see Gregory A. Kimble, Michael Wertheimer and Charlotte White, eds. Portraits of Pioneers in Psychology (Washington, D.C., and Hillsdale, NJ: American Psychological Association and Lawrence Erlbaum Associates, 1991) Morton Hunt, The Story of Psychology (New York Doubleday, 1993); Robert C. Bolles, The Story of Psychology: A Thematic History (Pacific Grove, CA: Brooks/Cole, 1993); and Mitchell G. Ash, Ge stalt Psychology in German Culture, 1890-1967: Ho lism and the Quest for Objectivity (Cambridge, U.K. Cambridge Univ. Press, 1995)

2. Regarding Ehrenfels, see Ash [1] pp. 88ff; and Fritz Heider, "Gestalt Theory: Early History and Reminiscences," in Mary Henle, Julian Jaynes and John J. Sullivan, eds., Historical Conceptions of Psychology (New York: Springer, 1973).

3. Ash [1] pp. 118ff

4. There is a brief but vivid recollection of student life at the Psychological Institute in Rudolf Arnheim, "My Life in the Art World," a talk presented at the School of Art, Univ. of Michigan, Ann Arbor, on 8 February 1984. The list of names provided here was verified through my correspondence with Arnheim.

5. The story of Köhler's courageous attempt to preserve the Psychological Institute is told in Mary Henle, "One Man Against the Nazis-Wolfgang Köhler," American Psychologist 33, No. 10, 939-944 (1978).

6. Rudolf Arnheim, "Das Bauhaus in Dessau," Die Weltbühne (1927); translated by Arnheim as "The Bauhaus in Dessau,"Print 51, No. 6, 60-61 (1997). Arnheim was 23 years old in 1927 when he traveled to Dessau from Berlin to visit the Bauhaus, which had moved there from Weimar the previous year. Arnheim told me in a letter dated 16 June 1993 that during his visit he saw only the buildings, be cause "it was in the summer and nobody, either famous or infamous, was around that I remember."

7. A photograph of Lewin's home, designed by Behrens and Breuer, is found in Tilmann Buddenseig, ed., Berlin 1900-1933: Architecture and Design (New York and Berlin: Cooper-Hewitt Museum and Gebr. Mann Verlag, 1987) p. 30.

8. Regarding Duncker's Bauhaus lecture and Wertheimer's influence on Klee, see Marianne Teuber, "Blue Night by Paul Klee," in Mary Henle, ed., Vision and Artifact (New York: Springer, 1976) pp. 131-151.

9. See Teuber [8] p. 144 . 
10. Regarding simultaneous contrast, see MichelEugene Chevreul, The Principles of Harmony and Con trast of Colors (New York: Garland, 1980); and Josef Albers, Interaction of Color (New Haven, CN: Yale Univ. Press, 1972).

11. For illustrated discussions of Froebel and his influence on art and design, see Ellen Lupton and J. Abbott Miller, eds., The ABC's of $\triangle \square$ The Bauhaus and Design Theory (New York: Princeton Architectural Press, 1991); and Norman Brosterman, In venting Kindergarten (New York: Harry N. Abrams, 1997).

12. See Karl Duncker, "On Problem-Solving," in John F. Dashiell, ed., Psychological Monographs 58, No. 5 (1945).

13. See Teuber [8].

14. For the application of Wertheimer's grouping principles to camouflage, artwork and page layouts, see Roy R. Behrens, "Illustration as Design," in Illus tration as an Art (Englewood Cliffs, NJ: Prentice Hall, 1986) chapter 1 .
15. Teuber [8] p. 134.

16. See György Kepes, Language of Vision (Chicago, IL: Paul Theobald, 1944; New York: Dover, 1996) László Moholy-Nagy, Vision in Motion (Chicago, IL: Paul Theobald, 1947); and Rudolf Arnheim, Art and Visual Perception: A Psychology of the Creative Eye (Berkeley, CA: Univ. of California Press, 1954; revised 1974).

17. Ellen Lupton and J. Abbott Miller, Design Writing Research: Writing on Graphic Design (New York: Princeton Architectural Press, 1996) p. 62.

18. Quoted in Wylie Sypher, Rococo to Cubism in Art and Literature (New York: Vintage Books, 1960) pp. 144-145.

19. Quoted in Robert Goldwater and Marco Treves, eds., Artists on Art (New York: Pantheon, 1945) p. 347.

20. See Ernest Fenollosa, The Masters of the Ukiyo(New York: Knickerbocker Press, 1896); Arthur Dow, Composition (Boston, MA: J.M. Bowles, 1899);
Denman Ross, A Theory of Pure Design (Boston, MA: Houghton Mifflin, 1907); and Kakuzo Okakura, The Book of Tea (Boston, MA: Fox, Duffield and Company, 1906). A discussion of the influence of these books, the aesthetic movement and Japonisme is found in Kevin Nute, Frank Lloyd Wright and Japan (New York: Van Nostrand Reinhold, 1993).

21. Nute [20] p. 127.

22. See Behrens [14] p. 14; and Nute [20] p. 98

23. Rudolf Arnheim, letter to the author dated 6 July 1995.

24. See Rudolf Arnheim, The Split and the Structure (Berkeley, CA: Univ. of California Press, 1996).

25. Rudolf Arnheim, To the Rescue of Art (Berkeley, CA: Univ. of California Press, 1992) p. viii.

26. Lupton and Miller [17] p. 62

Manuscript received 19 December 1996 